\title{
Effects of chestnut addition on physicochemical composition, total phenolic contents, antioxidant capacities and sensory properties of milk
}

\author{
Gaye I. ERDOĞAN, Ayşe Neslihan DÜNDAR
}

Cite this article as:

Erdoğan, E.I., Dündar, A.N. (2022). Effect of chestnut addition on physicochemical composition, total phenolic contents, antioaxidant capacities and sensory properties of milk. Food and Health, 8(1), 12-22. https://doi.org/10.3153/FH22002

Bursa Technical University, Faculty of Engineering and Natural Sciences, Department of Food Engineering, Yildırım, Bursa, Turkey

RCID IDs of the authors: G.I.E. 0000-0003-2084-7076 A.N.D. 0000-0002-1169-2079

Submitted: 29.03 .2021

Revision requested: 03.05.2021

Last revision received: 10.05 .2021

Accepted: 12.07 .2021

Published online: 13.11.2021

Correspondence:

Ayşe Neslihan DÜNDAR

E-mail: ayse.dundar $@$ btu.edu.tr

\section{ABSTRACT}

Chestnut-added milk (CM) was produced with 2 different methods. In the first method, chestnuts were roasted, and in the second method, they were cooked in bain-marie and then added to milk at different ratios $(5,15,25 \%)$. The addition of chestnuts to milk statistically increased the amount of protein, dietary fiber, carbohydrate, energy, mineral ( $\mathrm{Ca}, \mathrm{K}, \mathrm{P}, \mathrm{Mg})$, antioxidant capacity and total phenolic content compared to the control, whereas it did not cause a significant change in sensory properties. Therefore, the chestnut is a suitable supplementation for milk.

Keywords: Milk, Chestnut, Stevia, Functional dairy product

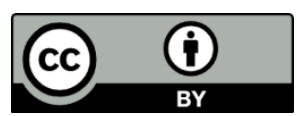




\section{Introduction}

Chestnut tree, one of the first known food sources of humankind, is also known as 'bread tree' (Bounous et al., 2000). It is seen that although nuts generally have a high fat content, this is different for chestnuts. Chestnut, which has a higher amount of carbohydrates, is also extremely nutritious (Dassler and Heitmann, 1991). This fruit, which has an important place in Turkish and world cuisine, is preferred as a candy in addition to being consumed by roasting or boiling. Antioxidant capacity of chestnuts taken from different provinces in Turkey on walnuts and chestnuts were determined by FRAP method and determined between 9.08-14.15 $\mathrm{mM} \mathrm{Fe}_{2} \mathrm{SO}_{4}$. In the same study, no significant difference was found in terms of antioxidant activity of raw, boiled, roasted chestnuts purchased from 3 different provinces (Selek, 2011).. Rich antioxidant content, minerals in its structure, and low but high quality fat content are among the reasons why chestnuts are preferred in diets today (Atasoy and Altıngoz, 2011).

The benefits of milk, which is one of our most nutritionally staple foods, have been described for centuries. Consumption of milk, which is known to be protected from many diseases such as osteoporosis, bowel cancer, high blood pressure, and chronic bronchitis, is extremely important (Altun et al., 2002.) The consumption of milk, which is considered to be an extremely important nutrient all over the world, unfortunately falls far behind other countries in our country. Considering all these, alternative solutions to increase milk consumption attract attention (Besler and Unal, 2008). For people who cannot consume milk and who do not appeal to the taste buds, much different flavored milk is produced with the developing technology today. Different kinds of flavored and fruit milk have been sold in the markets for a long time. In particular, the target audience of these products is children who do not like milk. However, chestnut milk samples, which suits Turkish palate and has been in our kitchens for a long time, has not been found yet.

As a natural sweetener that gives the usual sugar taste, stevia is one of the most popular products of recent time. The main feature that distinguishes stevia from other sweeteners is that it is heat resistant and does not leave an intense metallic taste in the mouth (Inanc and Cinar, 2009). Today, it is known that it is used in beverages, jam, pudding cooked by boiling, bakery foods such as cakes and cookies, confectionery industry, seafood, some vegetables, and tea sugar as well as in the production of many foods such as sushi, soy sauce, yoghurt (Kinghorn et al., 2001; Nunes et al., 2007). The objective of this study was to produce an alternative beverage with a high nutritional value, new flavor, and natural sweetener and to determine this product's features.

\section{Materials and Methods}

UHT full-fat cow's milk, frozen chestnut and stevia (Energy $0 \mathrm{Kcal}$, Fat $0 \mathrm{~g}$, saturated fat $0 \mathrm{~g}$, monounsaturated fat $0 \mathrm{~g}$, trans fat $0 \mathrm{~g}$, polyunsaturated fat $0 \mathrm{~g}$, cholesterol $0 \mathrm{~g}$, carbohydrate $0 \mathrm{mg}$, sugar $0 \mathrm{~g}$, sugar alcohol $0 \mathrm{~g}$, starch $0 \mathrm{~g}$, fiber $0 \mathrm{~g}$, protein $0 \mathrm{~g}$, salt sodium $0 \mathrm{~g}$, vitamin $0 \mathrm{~g}$, mineral $0 \mathrm{~g}$ and 5 drops of Stevia $=1$ cube of sugar) used in the production of the chestnut-added milk (CM) samples were obtained from the market. Chestnut fruit, in general has $40-45 \%$ water, 3$6 \%$ protein, $3-5 \%$ fat, $40-45 \%$ carbohydrate, $1.3 \%$ ash. However, these values may vary based on the ecological conditions, type, genus and process (Soylu, 2004). The samples were prepared fresh before the analysis.

\section{Production of Chestnut-Added Milk Samples}

In the production of the CM samples, heat treatment was applied to chestnuts according to 2 different methods. In the first method, chestnuts roasted in the oven at $150{ }^{\circ} \mathrm{C}$ for 30 minutes were called RCs, and in the second method, chestnuts cooked in a bain-marie were called BCs. Cooked chestnuts were added to hot UHT full- fat cow's milk $(100 \mathrm{ml})$ in different amounts $(5,15$, and $25 \mathrm{~g})$ with liquid stevia $(5 \mathrm{~mL})$ and homogenized by mechanical mixing with a blender (Waring, 8011S)

\section{Physico-Chemical Analysis of Chestnut Milk Samples}

The dry matter, fat, total sugar, protein, acidity, and dietary fiber of the milk (control) and CM samples were determined according to The Association of Official Analytical Chemists (AOAC) Approved Methods of Analysis Methods No: 990.20, 2000.18, 980.13, 991.20, 947.05, 991.43, respectively (Anonymous, 2000). Atwater factor was used for the calculation of the total carbohydrate and energy of the prepared samples (FAO, 2003).

The color measurements of the milk and CM samples were carried out by Minolta Spectrophotometer CM 3600d (Osaka, Japan) in order to measure $L^{*}, a^{*}$ and $b^{*}$ values. The results were expressed using the CIELab system. $L^{*}$ defines lightness or darkness, $a^{*}$ redness or greenness, and $b^{*}$ yellowness or blueness.

\section{Determination of Mineral Contents}

In mineral determination, the samples were digested by closed system wet combustion (microwave oven) method by modifying NMKL 1862007 and TS EN 138052004 methods. Microwave digestion system was used during the sample preparation. $2 \mathrm{~mL}$ of liquid from the homogenized samples was weighed with microwave vessels. To homogenize the sample, $8 \mathrm{~mL}$ of $\mathrm{HNO}_{3}(65 \%)$ and $2 \mathrm{~mL} \mathrm{H} \mathrm{H}_{2}(35 \%)$ were 
added. By applying the analysis program, which is given in Table 1, the samples were analyzed in microwave. The element content of the samples was automatically measured and calculated with a ICP-MS (7700) Agilenet which uses the calibration curve. The performance characteristics of the method for the analyzed five elements are given in Table 2.

\section{Extraction of Phenols}

The extraction method applied to the milk and CM samples was conducted according to Vitali et al., (2009) with some minor modifications. Briefly, $2 \mathrm{~mL}$ were taken from each samples and mixed with $\mathrm{HCl}_{\text {cond }}$ methanol/water $(1: 80: 10$, $\mathrm{v} / \mathrm{v}$ ) and shaken in a water bath (Nuve/ ST30, Turkey) at $20^{\circ} \mathrm{C}$ (250 rpm, 2h). The extracts were centrifuged (Hettich / Universal $320 \mathrm{R}$, Germany) at $3500 \mathrm{rpm}$ and $4{ }^{\circ} \mathrm{C}$ for $10 \mathrm{~min}$. The supernatant was used in the analyses of total phenolic content and antioxidant capacity.

\section{Determination of Total Phenolic Content and Antioxidant Capacity}

The total phenolic content of the milk and CM samples was determined according to Folin-Ciocalteu method (Naczk and Shahidi, 2004; Vitali et al., 2009). Gallic acid was used as a standard, and the results were expressed as $\mathrm{mg} \mathrm{GAE} / \mathrm{L}$.

Many methods are encountered in the literature to determine the antioxidant capacity. These methods have advantages and disadvantages compared to each other. Considering the selectivity and applicability of the methods, it is recommended to compare antioxidant capacity determinations using more than one method. Therefore, DPPH (2,2diphenyl-1-picrylhydrazyl), ABTS [2,2-azinobis (3ethylbenzothiazoline-6-sulphonic acid)], and CUPRAC (Cupric ion reducing antioxidant capacity) methods were used to determine the antioxidant capacity (Apak et al., 2004; Vitali et al., 2009). A calibration curve was prepared with Trolox (6-hydroxy-2,5,7,8 tetramethyl chroman-2-carboxylic acid), and the results were expressed as $\mu \mathrm{M}$ TEAC for each method.

\section{Sensory Evaluation}

The sensory evaluation of the milk and CM samples was carried out by 45 untrained panelists whose ages were between 17 to 40 . The hedonic scale with 9-points was used for sensorial evaluation. The samples were evaluated in terms of appearance, consistency, color, taste and overall acceptability.

\section{Statistical Evaluation}

The data were evaluated using SPSS 22 software program for statistical analysis. Differences among the means were analyzed by the one-way analysis of variance (ANOVA) applied for parametric tests. Based on the test results, the level of significance among the means $(\mathrm{p} \leq 0.05)$ were determined by
Duncan test. The statistical analyzes made within the group are shown in lower case, whereas the analyzes for all the samples are shown in capital letters.

Table 1. Heating program in microwave digestion system

\begin{tabular}{lllll}
\hline $\begin{array}{l}\text { Power } \\
(\mathbf{W})\end{array}$ & $\begin{array}{l}\text { Pressure } \\
(\mathbf{P S I})\end{array}$ & $\begin{array}{l}\text { Heat } \\
\left({ }^{\mathbf{0}} \mathbf{C}\right)\end{array}$ & $\begin{array}{l}\text { Ramp } \\
(\mathbf{m i n s})\end{array}$ & $\begin{array}{l}\text { Hold } \\
(\text { mins })\end{array}$ \\
\hline 250 & 250 & 180 & 5 & 1 \\
0 & 280 & 180 & 0 & 1 \\
250 & 320 & 220 & 1 & 5 \\
400 & 340 & 220 & 1 & 5 \\
650 & 400 & 220 & 3 & 5 \\
\hline
\end{tabular}

Table 2. Performance characteristics of the method

\begin{tabular}{ccc}
\hline $\begin{array}{c}\text { Ele- } \\
\text { ments }\end{array}$ & $\begin{array}{c}\text { Detection limit } \\
(\mathbf{m g} / \mathbf{L})\end{array}$ & $\begin{array}{c}\text { Quantification limit } \\
(\mathbf{m g} / \mathbf{L})\end{array}$ \\
\hline $\mathrm{Na}$ & 3.75 & 12.5 \\
$\mathrm{Ca}$ & 3.75 & 12.5 \\
$\mathrm{~K}$ & 3.75 & 12.5 \\
$\mathrm{P}$ & 3.75 & 12.5 \\
$\mathrm{Mg}$ & 0.09 & 0.3 \\
\hline
\end{tabular}

\section{Results and Discussion}

\section{Physico-Chemical Analysis of CM Samples}

Some physicochemical analysis results of the CM samples are given in Table 3. As the increased amount of chestnut in milk, the dry matter content also increased. In the RC samples, more dry matter amount was determined compared to the $\mathrm{BC}$ samples. The lowest value was determined as $5 \% \mathrm{BCs}$ (13.67), whereas the highest value was determined as $25 \%$ RCs (20.74). It is estimated that there was some loss of dry matter dissolved in water during the bain-marie and that chestnuts might have taken water into its structure by being affected by water vapor. Although chestnut is a nut, it is rich in carbohydrates and poor in fat (1.5-2.0\%) and protein (2.5$3.0 \%$ ), unlike nuts, such as walnuts and hazelnuts (Johnsen, 1992). Yurdakul (2008) determined the fat values of fresh chestnuts, boiled chestnuts and roasted chestnuts as 1.8-2.5\%, $1.3 \%, 2.2 \%$, respectively. As the chestnut ratio of the samples increased, the percentage of the fat content decreased. The fat content of the milk used in the samples is expected to be effective in the final product. The average fat of the milk used was found as $3.10 \pm 0.08 \%$. There is no statistically significant difference between BCs. In RCs, the fat content of the sample with $25 \%$ chestnut was significantly lower than the other samples. 
Table 3. Chemical analyzes of chestnut milk samples

\begin{tabular}{|c|c|c|c|c|c|c|c|c|c|}
\hline Method & $\begin{array}{l}\text { Chestnut } \\
\text { Ratio (\%) }\end{array}$ & $\begin{array}{c}\text { Dry Matter } \\
\text { Content (\%) }\end{array}$ & $\begin{array}{c}\text { Total } \\
\text { Sugar }(\%)\end{array}$ & $\begin{array}{l}\text { Fat } \\
(\%)\end{array}$ & $\begin{array}{c}\text { Protein } \\
(\%)\end{array}$ & $\begin{array}{c}\text { Acidity } \\
(\%)\end{array}$ & $\begin{array}{c}\text { Dietary } \\
\text { Fiber }(\%)\end{array}$ & $\begin{array}{c}\text { Carbohydrate } \\
(\%)\end{array}$ & $\begin{array}{c}\text { Energy } \\
(\mathrm{kcal} / \mathbf{1 0 0 \mathrm { mL }})\end{array}$ \\
\hline \multirow{3}{*}{ Bain-marie } & 0 & $8.0 \pm 0.1^{\mathrm{dG}}$ & $4.39 \pm 0.04^{\mathrm{cE}}$ & $3.10 \pm 0.01^{\mathrm{aA}}$ & $2.90 \pm 0.02^{\mathrm{cE}}$ & $0.13 \pm 0.01$ & $0^{\mathrm{dG}}$ & $5.93 \pm 0.06^{\mathrm{dG}}$ & $64.70 \pm 0.40^{\mathrm{dF}}$ \\
\hline & 5 & $13.67 \pm 0.30^{\mathrm{cF}}$ & $4.35 \pm 0.08^{\mathrm{cE}}$ & $3.13 \pm 0.22^{\mathrm{aA}}$ & $3.18 \pm 0.02^{\mathrm{bC}}$ & $0.12 \pm 0.01$ & $0.18 \pm 0.01^{\mathrm{cE}}$ & $6.70 \pm 0.38^{\mathrm{cF}}$ & $67.19 \pm 1.82^{\mathrm{cE}}$ \\
\hline & 15 & $16.30 \pm 0.21^{\mathrm{bE}}$ & $5.83 \pm 0.16^{\mathrm{bB}}$ & $2.72 \pm 0.56^{\mathrm{aA}}$ & $3.39 \pm 0.01^{\mathrm{aB}}$ & $0.12 \pm 0.02$ & $0.48 \pm 0.01^{\mathrm{bC}}$ & $9.40 \pm 0.60^{\mathrm{bD}}$ & $74.66 \pm 3.41^{b D}$ \\
\hline \multirow{5}{*}{ Roasted } & 25 & $18.89 \pm 0.38^{\mathrm{aD}}$ & $6.48 \pm 0.44^{\mathrm{aA}}$ & $2.65 \pm 0.46^{\mathrm{aB}}$ & $3.38 \pm 0.01^{\mathrm{aB}}$ & $0.13 \pm 0.02$ & $0.78 \pm 0.02^{\mathrm{aA}}$ & $12.0 \pm 0.46^{\mathrm{aB}}$ & $83.73 \pm 2.59^{\mathrm{aB}}$ \\
\hline & 0 & $8.0 \pm 0.1^{\mathrm{dG}}$ & $4.39 \pm 0.04^{\mathrm{aE}}$ & $3.10 \pm 0.01^{\mathrm{aA}}$ & $2.90 \pm 0.02^{\mathrm{dE}}$ & $0.13 \pm 0.01$ & $0^{\mathrm{dG}}$ & $5.93 \pm 0.06^{\mathrm{dG}}$ & $64.70 \pm 0.40^{\mathrm{dF}}$ \\
\hline & 5 & $15.68 \pm 0.02^{\mathrm{cC}}$ & $4.39 \pm 0.06^{\mathrm{aE}}$ & $3.05 \pm 0.10^{\mathrm{aA}}$ & $3.09 \pm 0.01^{\mathrm{cD}}$ & $0.11 \pm 0.01$ & $0.10 \pm 0.01^{\mathrm{cF}}$ & $8.85 \pm 0.12^{\mathrm{cE}}$ & $75.00 \pm 0.65^{\mathrm{cD}}$ \\
\hline & 15 & $17.11 \pm 0.03^{\mathrm{bB}}$ & $4.81 \pm 060^{\mathrm{abD}}$ & $3.00 \pm 0.18^{\mathrm{aA}}$ & $3.18 \pm 0.01^{\mathrm{bC}}$ & $0.12 \pm 0.01$ & $0.34 \pm 0.01^{\mathrm{bD}}$ & $10.13 \pm 0.18^{\mathrm{bC}}$ & $79.58 \pm 1.60^{\mathrm{bC}}$ \\
\hline & 25 & $20.74 \pm 0.03^{\mathrm{aA}}$ & $5.27 \pm 0.84^{\mathrm{bC}}$ & $2.65 \pm 0.16^{\mathrm{bB}}$ & $3.52 \pm 0.02^{\mathrm{aA}}$ & $0.13 \pm 0.03$ & $0.68 \pm 0.01^{\mathrm{aB}}$ & $13.69 \pm 0.18^{\mathrm{aA}}$ & $91.30 \pm 2.10^{\mathrm{aA}}$ \\
\hline
\end{tabular}

All data are expressed as mean \pm standard deviations $(n=3)$. Mean values showed with different lower letters in the same column for each chestnut addition levels are significantly different $(\mathrm{p} \leq 0.05)$. Mean values showed with different capital letters in the same column for each milk samples are significantly different $(\mathrm{p} \leq 0.05)$

Using the natural sweetener stevia in the product, which is an alternative to sweeteners used in dairy products, was tried. In a study on the addition of different sweeteners to chocolate milk, the sweetening power equivalent of stevia was stated as 70 sucrose (7\%). This value remained lower than other sweeteners such as aspartame and neotame (Paixão et al., 2014). The total sugar of chestnuts in dry matter was determined to be between 10.32-22.79\% (Ertürk et al., 2006). In a study conducted on 3 different chestnut species in Italy, the total sugar amount of chestnuts was found to be between 14.28$21.23 \%$ (Neri et al., 2010). It was determined that as the chestnut ratio increased, the total sugar amounts of BCs and $\mathrm{RCs}$ increased. The highest value was detected in the $25 \%$ BC sample $(6.48 \%)$, while the lowest value was found in the control $(4.39 \%)$.

Cow's milk contains high quality protein. The amount of protein in milk is stated as 3-3.5\% on average. While the structure of the protein is mainly composed of casein and whey proteins, it also contains enzymes and other compounds in its structure (Fox, 2003). Milk protein with a high content of essential amino acids is accepted as a quality protein and is used as a standard reference in the evaluation of protein quality in foods (Arabacioglu, 1993; Miller et al., 2000; Baysal, 2004). While the protein values of fresh chestnuts vary between 3.2$5 \%$, this value was determined as $2 \%$ for boiled chestnuts and $3.2 \%$ for roasted chestnuts (Yurdakul, 2008). The lowest protein content in the samples was found to be $2.90 \%$ in the control, whereas the highest value was found as $3.52 \%$ in $25 \%$ $\mathrm{RC}$. The addition of chestnut increased protein contents in the milk samples significantly. The values we found in our study were similar to those in the literature.

Determining the acidity level is important for the status of storage conditions, the decision of the heat treatment to be applied, the presence of any imitation, adulteration, and animal disease (Kurdar, 2001). In a study conducted to determine some quality criteria of UHT milks, the Soxhlet-Henkel degrees values of titration acidity of milk, strawberry flavored milk and chocolate milk were $7.73 ; 7.73 ; 6.67$, respectively (Sonmez et al., 2010). Titration acidity in mango milk was found to be $0.14 \%$ in a study (Bajwa, 2013). The acidity value was similar to the mango milk sample, and the values were found to be $0.11-0.14 \%$. The acidity values of CMs were not affected by the applied method and chestnut ratio.

The fiber content of chestnuts are polysaccharides, which stems from hemicellulose, cellulose and lignin in the cell wall (Van Soest, 1994). Most of them cannot be digested by the body, but can contribute to the development of the intestinal flora. Chestnut is recommended in diets to reduce the risk of cardiovascular and cancer diseases (Yurdakul, 2008; Candemir, 2011). While the fiber content in fresh chestnuts was determined as $8-10 \%$, this ratio decreases to $0.7 \%$ and $0.9 \%$, respectively, in boiled and roasted chestnuts (Yurdakul, 2008). The average fiber content of chestnut used in the CM samples was found to be $2.22 \pm 0.01 \%$. The highest dietary fiber value was observed in $25 \% \mathrm{BC}(0.78 \%)$, while the lowest dietary fiber content was observed in the control $(0 \%)$ as expected. It was seen that as the amount of chestnut increased, the ratio of dietary fiber increased. It was observed that by adding a source of fiber to milk, a beverage that does not contain dietary fiber, a functional feature was added to the final product.

When the nutritional elements of chestnuts are examined, it is seen that almost half of them are carbohydrates. It has an average carbohydrate content of $44.7 \%$. Starch constitutes most of the carbohydrate with $25 \%$. Amylose and amylopectin forms of starch have positive effects on human health due to energy values and intestinal activities. The distinctive taste of the fruit when cooked is due to starch (Bernárdez, 2004; Yurdakul, 2008; De Vasconcelos et al., 2010; Candemir, 2011). The carbohydrate of milk was calculated as $5.93 \pm$ 
$0.06 \%$ and $39.67 \pm 0.01 \%$ for chestnuts. The energy values of the raw materials were calculated as $64.70 \pm 0.40 \mathrm{kcal}$ and 181 $\pm 4.6 \mathrm{kcal}$, for milk $(100 \mathrm{~mL})$ and chestnuts $(100 \mathrm{~g})$. As the ratio of chestnuts increased, the carbohydrate and energy values increased. While the sample with the highest carbohydrate and energy value was the $25 \% \mathrm{RC}$ sample, the lowest sample was observed in the $5 \% \mathrm{BC}$ sample. In the chestnuts added at the same ratio, it was observed that the roasted method had more carbohydrate and energy value than the bain-marie method. This difference was similar to the studies in the literature. In a study, it was determined that when the chestnut was boiled, the moisture content increased and the total energy value decreased by $25 \%$ to $120 \mathrm{kcal}$. The starch composition also changed during boiling. When roasted, the humidity rate decreased by $20 \%$, the amount of sugar increased by $25 \%$ and the energy value increased to $200 \mathrm{kcal}$. (Neri et al., 2010) In another study, the energy values given for 100 grams of fresh chestnuts, boiled chestnuts and roasted chestnuts were stated to be 160-199, 131, $245 \mathrm{kcal}$, respectively (Yurdakul, 2008).

There are a few studies on the color analysis of milk and dairy products. The color values of the produced CM samples were affected by the milk and chestnuts used. Color analysis results of the CM samples are given in Table 4. In this study, the color values of chestnuts were found to be $76.50 \pm 0.1$ for $L^{*}$; $1.88 \pm 0.05$ for $a^{*}$; and $16.60 \pm 0.47$ for $b^{*}$. These values were close to the literature values. At the same ratio, the $L^{*}$ values of the BC samples were higher than the RC samples. The $L^{*}$ value decreased as the chestnut ratio increased. The $a^{*}$ value of the milk used in the samples was measured as $-0.45 \pm 0.01$. When the $a^{*}$ values of the samples were examined, the highest redness value was the $25 \%$ RC sample and the lowest was the 5\% BC sample. As the chestnut ratio increased, the degree of redness increased. The redness of the roasted samples added at the same ratio was higher than the bain-marie. It is estimated that the dark colored compounds formed by enzymatic and non-enzymatic reactions because this color change observed with the effect of baking. The $b^{*}$ value of the milk used in the samples was determined as $12.37 \pm 0.03$. The $b^{*}$ value decreased when the chestnut ratio increased. In addition, the $\mathrm{BC}$ samples had higher $b^{*}$ values than the RC samples.

\section{Mineral Contents}

Chestnut is especially rich in terms of $\mathrm{K}, \mathrm{P}, \mathrm{Mg}, \mathrm{Fe}, \mathrm{Mn}$ and $\mathrm{Cu}$ content (Diehl, 2002). When the CM samples were examined, it was found that the $\mathrm{K}, \mathrm{P}, \mathrm{Ca}, \mathrm{Na}$ and $\mathrm{Mg}$ contents were high, respectively. As the ratio of added chestnut increases, the amount of mineral content increases (except $\mathrm{Na}$ ). As the chestnut ratio increased, the sodium content decreased. Some studies had shown that heat treatment applied to milk reduced the amount of $\mathrm{Na}$ (Yurdakul, 2008; Neri et al., 2010), which was similar to this study. The mineral content results of the CM samples are given in Table 5. When the calcium values were evaluated; there was no statistically significant difference between those containing $15 \%$ and $25 \%$ chestnut. On the other hand, the samples containing milk and $5 \%$ chestnut were statistically the same. Considering the data as potassium in terms of method, it was observed that the roasted samples had a higher content than the bain-marie samples. The highest value in terms of phosphorus was observed in $25 \%$ roasted chestnut. In magnesium analysis, no statistically significant difference was observed in those containing $5 \%$ chestnut, and the roasted samples were higher than the bain-marie ones.

\section{Antioxidant Capacity}

The antioxidant capacity analysis determined according to methods of ABTS, CUPRAC, and DPPH assays. The absorbance of the extracts was determined spectrophotometrically (Jenway, $6405 \mathrm{UV} / \mathrm{Vis}$ ). The antioxidant capacity results of the CM samples are given in Table 6. The ABTS values of the samples were found to be between 33-328 $\mu \mathrm{M}$ TEAC, and the antioxidant capacity of the samples increased as the amount of chestnuts added increased. Changing the heat treatment method of chestnuts had no effect on their antioxidant capacity. In a study conducted in Turkey on the antioxidant capacity of pasteurized and UHT milk, milk (3.2\% fat), partially-skimmed (1.8\%) and skimmed UHT milk, ABTS average values were determined as $240.30 \pm 1.06,209.81$ $\pm 2.16 ; 216.78 \pm 4.81 \mu \mathrm{M}$ TEAC, respectively (Ertan et al., 2017), and it was observed to be higher than the values we determined. This difference is thought to be due to the composition of UHT milk which was used in our study.

The antioxidant capacities of the samples were determined between 60710-77496 $\mu \mathrm{M}$ TEAC values with the CUPRAC method, which were the highest values determined in the antioxidant capacity analyses. It was observed that the ratio of added chestnuts increased the antioxidant capacity and that the chestnut cooking method, however, had no effect on the capacity.

The antioxidant capacity values of 5262-6099 $\mu \mathrm{M}$ TEAC of the samples were determined with the DPPH method. As in the other methods, as the ratio of added chestnut amounts increased, the capacity values increased, and the heat treatment method applied to chestnuts had no effect. 
Table 4. Color values of chestnut milk samples

\begin{tabular}{lllll}
\hline Method & Chestnut Ratio (\%) & $\boldsymbol{L}^{*}$ & $\boldsymbol{a}^{*}$ & $\boldsymbol{b}^{*}$ \\
\hline \multirow{3}{*}{ Bain-marie } & 0 & $92.72 \pm 0.10^{\mathrm{aA}}$ & $-0.45 \pm 0.01^{\mathrm{cE}}$ & $12.37 \pm 0.03^{\mathrm{aA}}$ \\
& 5 & $87.50 \pm 0.32^{\mathrm{bB}}$ & $0.67 \pm 0.04^{\mathrm{aC}}$ & $11.79 \pm 0.36^{\mathrm{bB}}$ \\
& 15 & $85.75 \pm 0.43^{\mathrm{cC}}$ & $0.51 \pm 0.06^{\mathrm{bD}}$ & $11.13 \pm 0.36^{\mathrm{cC}}$ \\
& 25 & $84.45 \pm 0.05^{\mathrm{dD}}$ & $0.69 \pm 0.01^{\mathrm{aC}}$ & $11.01 \pm 0.08^{\mathrm{cC}}$ \\
Roasted & 5 & $92.72 \pm 0.10^{\mathrm{aA}}$ & $-0.45 \pm 0.01^{\mathrm{cE}}$ & $12.37 \pm 0.03^{\mathrm{aA}}$ \\
& 15 & $84.46 \pm 0.33^{\mathrm{bC}}$ & $1.34 \pm 0.09^{\mathrm{cB}}$ & $11.37 \pm 0.38^{\mathrm{bB}}$ \\
& 25 & $80.44 \pm 0.26^{\mathrm{cD}}$ & $2.52 \pm 0.14^{\mathrm{bA}}$ & $10.10 \pm 0.39^{\mathrm{cC}}$ \\
\hline
\end{tabular}

All data are expressed as mean \pm standard deviations $(n=3)$. Mean values showed with different lower letters in the same column for each chestnut addition levels are significantly different $(p \leq 0.05)$. Mean values showed with different capital letters in the same column for each milk samples are significantly different $(\mathrm{p} \leq 0.05)$.

Table 5. Mineral content values of chestnut milk samples

\begin{tabular}{lclllll}
\hline Method & $\begin{array}{c}\text { Chestnut } \\
\text { Ratio }(\%)\end{array}$ & $\mathbf{N a}(\mathbf{m g} / \mathbf{L})$ & $\mathbf{C a}(\mathbf{m g} / \mathbf{L})$ & $\mathbf{K}(\mathbf{m g} / \mathbf{L})$ & $\mathbf{P}(\mathbf{m g} / \mathbf{L})$ & $\mathbf{M g}(\mathbf{m g} / \mathbf{L})$ \\
& 0 & $366.90 \pm 1.30^{\mathrm{aA}}$ & $685.20 \pm 35.20^{\mathrm{dC}}$ & $1247.50 \pm 79.10^{\mathrm{cF}}$ & $834.40 \pm 10.0^{\mathrm{dE}}$ & $83.70 \pm 2.10^{\mathrm{dD}}$ \\
Bain- & 5 & $356.83 \pm 2.22^{\mathrm{bB}}$ & $707.45 \pm 8.99^{\mathrm{cC}}$ & $1272.47 \pm 11.38^{\mathrm{cF}}$ & $866.18 \pm 1.91^{\mathrm{cD}}$ & $89.83 \pm 0.64^{\mathrm{cE}}$ \\
marie & 15 & $337.35 \pm 1.46^{\mathrm{cD}}$ & $773.75 \pm 7.99^{\mathrm{bB}}$ & $1474.0 \pm 10.97^{\mathrm{bD}}$ & $936.95 \pm 10.54^{\mathrm{bC}}$ & $93.78 \pm 1.01^{\mathrm{bD}}$ \\
& 25 & $309.83 \pm 0.81^{\mathrm{dE}}$ & $807.52 \pm 12.70^{\mathrm{aB}}$ & $1591.83 \pm 42.46^{\mathrm{aB}}$ & $957.95 \pm 14.20^{\mathrm{aB}}$ & $109.47 \pm 1.65^{\mathrm{aC}}$ \\
& 0 & $366.90 \pm 1.30^{\mathrm{aA}}$ & $685.20 \pm 35.20^{\mathrm{bC}}$ & $1247.50 \pm 79.10^{\mathrm{dF}}$ & $834.40 \pm 10.0^{\mathrm{cE}}$ & $83.70 \pm 2.10^{\mathrm{dD}}$ \\
Roasted & 5 & $364.35 \pm 1.14^{\mathrm{aA}}$ & $688.52 \pm 10.31^{\mathrm{bC}}$ & $1311.98 \pm 19.05^{\mathrm{cE}}$ & $870.88 \pm 7.10^{\mathrm{bD}}$ & $94.37 \pm 0.33^{\mathrm{cE}}$ \\
& 15 & $358.22 \pm 1.42^{\mathrm{bB}}$ & $873.73 \pm 56.51^{\mathrm{aA}}$ & $1477.50 \pm 40.11^{\mathrm{bC}}$ & $950.02 \pm 12.81^{\mathrm{aBC}}$ & $105.48 \pm 7.56^{\mathrm{bB}}$ \\
& 25 & $344.47 \pm 1.06^{\mathrm{cC}}$ & $885.2 \pm 78.67^{\mathrm{aA}}$ & $1729.83 \pm 28.69^{\mathrm{aA}}$ & $982.17 \pm 17.68^{\mathrm{aA}}$ & $116.35 \pm 8.22^{\mathrm{aA}}$ \\
\hline
\end{tabular}

All data are expressed as mean \pm standard deviations $(n=3)$. Mean values showed with different lower letters in the same column for each chestnut addition levels are significantly different $(p \leq 0.05)$. Mean values showed with different capital letters in the same column for each milk samples are significantly different $(\mathrm{p} \leq 0.05)$.

\section{Total Phenolic Content}

In a study on different nuts, the total phenolic content of chestnut was stated as $92 \mathrm{mg} \mathrm{GAE} / 100 \mathrm{~g}$ dry matter (Abe et al., 2010). In the study on chestnuts and walnuts collected from different regions, the lowest total phenolic content of chestnuts was found to be $5 \mathrm{GAE} / \mathrm{g}$ dry matter, whereas the highest total phenolic content was $32.82 \mathrm{GAE} / \mathrm{g}$ dry matter (Selek, 2011). De Vasconcelos et al., (2007) found the total phenolic content of chestnuts as $15.80 \mathrm{mg} \mathrm{GAE} / \mathrm{g}$ dry matter.

The total phenolic contents of fat, semi-skimmed and skimmed milk were found to be $982.14 \mathrm{mg} \mathrm{GAE} / \mathrm{L}, 515.19$ mg GAE/L, 505.47 mg GAE/L, respectively, in Turkey (Ertan et al., 2017). In another study, strawberry milk, chocolate milk and milk were determined in the range of 1046.60$1414.60 \mathrm{mg}$ GAE/L, 834.60-2347.20 mg GAE/L, 936.60$1066.60 \mathrm{mg}$ GAE/L, respectively (Sonmez et al., 2010). The total phenolic content results of the CM samples are given in Table 6. The total phenolic content of the samples in our study was between 1628.7-2020.1 mg GAE/L, which was similar to the above mentioned study. As the ratio of chestnuts increased, the total phenolic content of the samples increased due to the total phenolic content of the chestnut. The heat treatment method applied to chestnuts did not cause statistical differences.

\section{Sensory Evaluation}

The sensory evaluation of the CM samples was performed by forty five untrained panelists including twenty males and twenty five females with ages ranging from 18 to 35 . Before starting the analysis, the necessary information was given to the panelists and the samples were given to the panelists by coding with 2-digit numbers. The product was evaluated in terms of appearance, consistency, color, taste and overall acceptability. The sensory evaluation results of the CM samples are given in Table 7 and Table 8.

When the appearance of the samples was examined, the heat treatment method and the rate of the addition of chestnuts did 
not make a significant difference. The panelists considered the intensity, fluidity and homogeneity sub-criteria while evaluating the consistency. The most desired sample by the panelists was the 5\% RC samples. The panelists scored for colour based on light, dark, matte and glossy sub criteria. As the amount of chestnut in the RC samples increased, the degree of liking decreased. No significant difference was observed in the evaluation of the BC samples or all the samples. the samples with $5 \%$ chestnut addition were most appreciated. In terms of taste, the most preferred one was the 5\% RC sample, whereas the least preferred one was the control sample. As the final assessment of sensory analysis, the panelists were asked to rate the overall liking of the samples. There was no difference between the $\mathrm{BC}$ samples. On the other hand, as the ratio of chestnuts increased in the RC samples, the acceptability decreased. When all the samples were evaluated, the 5\% RC sample was the most desired sample.

Table 6. Antioxidant capacity and total phenol content of chestnut milk samples

\begin{tabular}{llllll}
\hline Method & $\begin{array}{l}\text { Chestnut Ra- } \\
\text { tio }(\%)\end{array}$ & $\begin{array}{l}\text { ABTS } \\
(\boldsymbol{\mu M} \text { TEAC) }\end{array}$ & $\begin{array}{l}\text { CUPRAC } \\
(\boldsymbol{\mu M ~ T E A C})\end{array}$ & $\begin{array}{l}\text { DPPH } \\
(\boldsymbol{\mu M} \text { TEAC) }\end{array}$ & $\begin{array}{l}\text { Total Phenolic Content } \\
(\mathbf{m g} \text { GAE/L) }\end{array}$ \\
\hline \multirow{3}{*}{ Bain-marie } & 0 & $33.0 \pm 0.9^{\mathrm{dD}}$ & $60710 \pm 1485^{\mathrm{cC}}$ & $5262 \pm 794^{\mathrm{aC}}$ & $1628.7 \pm 43.0^{\mathrm{cC}}$ \\
& 5 & $89.8 \pm 2.8^{\mathrm{cC}}$ & $70656 \pm 2008^{\mathrm{bB}}$ & $5581 \pm 675^{\mathrm{aBC}}$ & $1864.3 \pm 32.2^{\mathrm{bB}}$ \\
& 15 & $181.3 \pm 6.5^{\mathrm{bB}}$ & $75826 \pm 580^{\mathrm{aA}}$ & $5906 \pm 556^{\mathrm{aAB}}$ & $1959.2 \pm 16.1^{\mathrm{abA}}$ \\
& 25 & $328.2 \pm 0.9^{\mathrm{aA}}$ & $77496 \pm 622^{\mathrm{aA}}$ & $5965 \pm 1706^{\mathrm{aA}}$ & $2020.1 \pm 37.6^{\mathrm{aA}}$ \\
Roasted & 0 & $33.0 \pm 0.9^{\mathrm{dD}}$ & $60710 \pm 1485^{\mathrm{aC}}$ & $5262 \pm 794^{\mathrm{dC}}$ & $1628.7 \pm 43.0^{\mathrm{cC}}$ \\
& 5 & $108.4 \pm 11.5^{\mathrm{cC}}$ & $65772 \pm 2828^{\mathrm{aC}}$ & $5507 \pm 1106^{\mathrm{cC}}$ & $1685.7 \pm 16.1^{\mathrm{bC}}$ \\
& 15 & $216.2 \pm 8.8^{\mathrm{bB}}$ & $67182 \pm 693^{\mathrm{aBC}}$ & $5985 \pm 774^{\mathrm{bcBC}}$ & $1754.1 \pm 59.1^{\mathrm{bC}}$ \\
& 25 & $310.5 \pm 24.0^{\mathrm{aA}}$ & $68622 \pm 184^{\mathrm{aBC}}$ & $6099 \pm 60^{\mathrm{bAB}}$ & $1993.5 \pm 21.5^{\mathrm{aA}}$ \\
\hline
\end{tabular}

All data are expressed as mean \pm standard deviations $(n=3)$. Mean values showed with different lower letters in the same column for each chestnut addition levels are significantly different $(\mathrm{p} \leq 0.05)$. Mean values showed with different capital letters in the same column for each milk samples are significantly different $(\mathrm{p} \leq 0.05)$.

Table 7. Sensory analysis sub criteria of chestnut milk samples

\begin{tabular}{|c|c|c|c|c|c|c|c|c|c|c|c|}
\hline \multirow[t]{2}{*}{ Method } & \multirow{2}{*}{$\begin{array}{l}\text { Chestnut } \\
\text { Ratio } \\
(\%)\end{array}$} & \multicolumn{3}{|c|}{ Appearance } & \multicolumn{3}{|c|}{ Consistency } & \multicolumn{3}{|c|}{ Color } & \multirow[b]{2}{*}{ Gloss } \\
\hline & & Homogeneous & s Particulate & Sediment & Density & Fluid & Homogeneity & Light & Dark & Matte & \\
\hline \multirow[t]{4}{*}{ Bain-marie } & 0 & $7.3 \pm 1.8^{\mathrm{A}}$ & $4.7 \pm 3.2^{\mathrm{A}}$ & $4.8 \pm 3.3^{\mathrm{A}}$ & $4.9 \pm 2.7^{\mathrm{A}}$ & $7.1 \pm 1.8^{\mathrm{A}}$ & $6.9 \pm 2.2^{\mathrm{A}}$ & $6.9 \pm 2.1^{\mathrm{A}}$ & $4.8 \pm 2.7^{\mathrm{AB}}$ & $5.5 \pm 2.4^{\mathrm{A}}$ & $6.5 \pm 2.1^{\mathrm{A}}$ \\
\hline & 5 & $6.9 \pm 1.9^{\mathrm{aA}}$ & $4.6 \pm 2.7^{\mathrm{aA}}$ & $4.7 \pm 2.9^{\mathrm{aA}}$ & $5.0 \pm 2.1^{\mathrm{aA}}$ & $7.0 \pm 1.4^{\mathrm{aA}}$ & $6.9 \pm 2.0^{\mathrm{aA}}$ & $6.5 \pm 1.8^{\mathrm{aA}}$ & $4.9 \pm 2.2^{\mathrm{aAB}}$ & $5.7 \pm 2.0^{\mathrm{aA}}$ & $5.9 \pm 2.0^{\mathrm{aAB}}$ \\
\hline & 15 & $7.1 \pm 2.1^{\mathrm{aA}}$ & $4.4 \pm 3.1^{\mathrm{aA}}$ & $4.5 \pm 3.2^{\mathrm{aA}}$ & $4.6 \pm 2.4^{\mathrm{aA}}$ & $7.1 \pm 1.9^{\mathrm{aA}}$ & $7.0 \pm 2.0^{\mathrm{aA}}$ & $6.7 \pm 2.0^{\mathrm{aA}}$ & $3.9 \pm 2.5^{\mathrm{bB}}$ & $5.02 \pm 2.4^{\mathrm{aA}}$ & $5.7 \pm 2.1^{\mathrm{aAB}}$ \\
\hline & 25 & $5.8 \pm 2.5^{\mathrm{bB}}$ & $4.7 \pm 2.8^{\mathrm{aA}}$ & $4.5 \pm 2.7^{\mathrm{aA}}$ & $5.1 \pm 2.2^{\mathrm{aA}}$ & $6.0 \pm 2.4^{\mathrm{bB}}$ & $5.7 \pm 2.7^{\mathrm{bB}}$ & $5.5 \pm 2.2^{\mathrm{bBC}}$ & $5.3 \pm 2.2^{\mathrm{aA}}$ & $5.5 \pm 2.3^{\mathrm{aA}}$ & $5.2 \pm 2.1^{\mathrm{aB}}$ \\
\hline \multirow[t]{4}{*}{ Roasted } & 0 & $7.3 \pm 1.8^{\mathrm{A}}$ & $4.7 \pm 3.2^{\mathrm{A}}$ & $4.8 \pm 3.3^{\mathrm{A}}$ & $4.9 \pm 2.7^{\mathrm{A}}$ & $7.1 \pm 1.8^{\mathrm{A}}$ & $6.9 \pm 2.2^{\mathrm{A}}$ & $6.9 \pm 2.1^{\mathrm{A}}$ & $4.8 \pm 2.7^{\mathrm{AB}}$ & $5.5 \pm 2.4^{\mathrm{A}}$ & $6.5 \pm 2.1^{\mathrm{A}}$ \\
\hline & 5 & $7.1 \pm 2.1^{\mathrm{bA}}$ & $4.9 \pm 3.2^{\mathrm{bA}}$ & $5.0 \pm 3.1^{\mathrm{bA}}$ & $5.6 \pm 2.4^{\mathrm{bA}}$ & $7.0 \pm 1.9^{\mathrm{cA}}$ & $7.0 \pm 1.9^{\mathrm{cA}}$ & $6.7 \pm 1.9^{\mathrm{cA}}$ & $5.1 \pm 2.4^{\mathrm{cA}}$ & $5.5 \pm 1.9^{\mathrm{bA}}$ & $6.3 \pm 1.8^{\mathrm{bA}}$ \\
\hline & 15 & $6.9 \pm 2.3^{\mathrm{bA}}$ & $4.6 \pm 3.0^{\mathrm{bA}}$ & $4.7 \pm 3.0^{\mathrm{bA}}$ & $5.5 \pm 2.4^{\mathrm{bA}}$ & $6.8 \pm 2.1^{\mathrm{cAB}}$ & $6.6 \pm 2.2^{\mathrm{cA}}$ & $6.1 \pm 2.0^{\mathrm{cAB}}$ & $5.4 \pm 2.3^{\mathrm{cA}}$ & $5.4 \pm 2.1^{\mathrm{bA}}$ & $5.8 \pm 1.9^{\mathrm{bcAB}}$ \\
\hline & 25 & $6.6 \pm 2.059^{\mathrm{bAB}}$ & $4.8 \pm 2.8^{\mathrm{bA}}$ & $4.9 \pm 2.9^{\mathrm{bA}}$ & $5.2 \pm 2.3^{\mathrm{bA}}$ & $6.7 \pm 2.0^{\mathrm{cAB}}$ & $6.5 \pm 2.1^{\mathrm{cAB}}$ & $5.2 \pm 2.1^{\mathrm{dC}}$ & $5.0 \pm 2.3^{\mathrm{cA}}$ & $5.4 \pm 2.2^{\mathrm{bA}}$ & $5.3 \pm 2.2^{\mathrm{cB}}$ \\
\hline
\end{tabular}

All data are expressed as mean \pm standard deviations $(n=3)$. Mean values showed with different lower letters in the same column for each chestnut addition levels are significantly different $(\mathrm{p} \leq 0.05)$. Mean values showed with different capital letters in the same column for each milk samples are significantly different $(\mathrm{p} \leq 0.05)$.

Table 8 . Sensory analysis of chestnut milk samples basic criteria

\begin{tabular}{|c|c|c|c|c|c|c|c|}
\hline Method & Chestnut Ratio (\%) & Appearance & Consistency & Color & Odor & Taste & Overall Acceptability \\
\hline \multirow{4}{*}{ Bain-marie } & 0 & $5.6 \pm 2.4^{\mathrm{A}}$ & $6.3 \pm 1.8^{\mathrm{AB}}$ & $5.9 \pm 1.8^{\mathrm{A}}$ & $5.4 \pm 2.5^{\mathrm{AB}}$ & $4.4 \pm 2.7^{\mathrm{C}}$ & $4.8 \pm 2.6^{\mathrm{B}}$ \\
\hline & 5 & $5.4 \pm 2.0^{\mathrm{aA}}$ & $6.3 \pm 13^{\mathrm{aAB}}$ & $5.8 \pm 1.2^{\mathrm{aA}}$ & $5.7 \pm 2.0^{\mathrm{aA}}$ & $5.1 \pm 1.9^{\mathrm{aBC}}$ & $5.0 \pm 1.9^{\mathrm{aB}}$ \\
\hline & 15 & $5.3 \pm 2.3^{\mathrm{aA}}$ & $6.2 \pm 1.7^{\mathrm{abAB}}$ & $5.3 \pm 1.5^{\mathrm{aA}}$ & $4.5 \pm 2.1^{\mathrm{bB}}$ & $4.8 \pm 2.3^{\mathrm{aBC}}$ & $5.0 \pm 2.0^{\mathrm{aB}}$ \\
\hline & 25 & $5.0 \pm 1.9^{\mathrm{aA}}$ & $5.6 \pm 2.0^{\mathrm{bB}}$ & $5.4 \pm 1.7^{\mathrm{aA}}$ & $5.0 \pm 2.0^{\mathrm{abAB}}$ & $4.7 \pm 2.3^{\mathrm{aBC}}$ & $4.5 \pm 2.1^{\mathrm{aB}}$ \\
\hline \multirow[t]{4}{*}{ Roasted } & 0 & $5.6 \pm 2.4^{\mathrm{A}}$ & $6.3 \pm 1.8^{\mathrm{AB}}$ & $5.9 \pm 1.8^{\mathrm{A}}$ & $5.4 \pm 2.5^{\mathrm{AB}}$ & $4.4 \pm 2.7^{\mathrm{C}}$ & $4.8 \pm 2.6^{\mathrm{B}}$ \\
\hline & 5 & $5.7 \pm 2.4^{\mathrm{bA}}$ & $6.5 \pm 1.7^{\mathrm{cA}}$ & $5.9 \pm 1.5^{\mathrm{bA}}$ & $5.9 \pm 2.2^{\mathrm{cA}}$ & $6.3 \pm 2.2^{\mathrm{bA}}$ & $6.0 \pm 2.2^{\mathrm{bA}}$ \\
\hline & 15 & $5.4 \pm 2.3^{\mathrm{bA}}$ & $6.3 \pm 1.8^{\mathrm{cAB}}$ & $5.7 \pm 1.4^{\mathrm{bcA}}$ & $5.4 \pm 2.2^{\mathrm{cAB}}$ & $5.6 \pm 2.3^{\mathrm{bcAB}}$ & $5.5 \pm 2.2^{\mathrm{bcAB}}$ \\
\hline & 25 & $5.5 \pm 2.0^{\mathrm{bA}}$ & $6.1 \pm 1.7^{\mathrm{cAB}}$ & $5.2 \pm 1.4^{\mathrm{cA}}$ & $4.6 \pm 2.1^{\mathrm{cdB}}$ & $4.8 \pm 2.3^{\mathrm{cBC}}$ & $4.9 \pm 2.0^{\mathrm{cB}}$ \\
\hline
\end{tabular}

All data are expressed as mean \pm standard deviations $(n=3)$. Mean values showed with different lower letters in the same column for each chestnut addition levels are significantly different $(\mathrm{p} \leq 0.05)$. Mean values showed with different capital letters in the same column for each milk samples are significantly different $(\mathrm{p} \leq 0.05)$. 


\section{Conclusion}

The purpose of investigating chestnut milk production and its properties is to produce a functional product and examine its properties. Chestnuts are actively processed in Turkey, especially in Bursa. Here, it is aimed to develop a product with high added value by developing a new product alternative to the market and increasing the usage possibilities of the product. The addition of chestnut to milk increased the mineral content of milk (except $\mathrm{Na}$ ) and added dietary fiber to the product content; however, it provided a beverage with more calories and high energy than milk. However, this energy increase was similar to all other flavoured milks. The addition of chestnuts to milk increased the antioxidant capacity and total phenolic content of the milk. In the sensory evaluation of the product, it was observed that the $5 \% \mathrm{RC}$ sample was preferred most, and even more preferred than milk. Also, stevia is a natural sweetener. Unlike artificial sweeteners, it does not leave metalish and bitter taste in the mouth. so it can be used as an alternative to artificial sweeteners.

As a result, chestnut could be expressed as a suitable nut for functional food formulations by increasing the bioactive potential and providing quality parameters and sensory evaluation. Chestnut-added milk is a beverage alternative that can be recommended especially to children who don't like to drink milk, pregnant women, sports and individuals who care about their diet.

\section{Compliance with Ethical Standard}

Conflict of interests: The author declares that for this article they have no actual, potential or perceived conflict of interests.

Ethics committee approval: Author declare that this study does not include any experiments with human or animal subjects.

Funding disclosure: This work was supported by the Scientific Research Council of Bursa Technical University, TURKEY (Project No: 172L18).

Acknowledgments: -

Disclosure: -

\section{References}

Abe, L.T., Lajolo, F.M., Genovese, M.I. (2010). Comparison of phenol content and antioxidant capacity of nuts. Ciência e Tecnologia de Alimentos, 30, 254-259. https://doi.org/10.1590/S0101-20612010000500038

Altun, B., Besler, T., Unal, S. (2002). Ankara'da Sat1lan Sütlerin Değerlendirilmesi, Sürekli Tip Eğitimi Dergisi, 11(2), 51-55.

Apak, R., Güçlü, K., Özyürek, M., Karademir, S. E. (2004). Novel Total Antioxidant Capacity Index for Dietary Polyphenols and Vitamins C and E, Using Their Cupric Ion Reducing Capability in the Presence of Neocuproine: CUPRAC Method. Journal of Agricultural and Food Chemistry, 52(26), 7970-7981.

https://doi.org/10.1021/jf048741x

Arabacioglu, O.Z. (1993). İçme Sütü Tüketiminin Arttırılması ve Okul Sütü Programları. 5. Türkiye Sütçülük Kongresi (p. 217) Ankara, Türkiye, 20-21 Mayıs 1993.

Anonymous (2000). Official Methods of Analysis, 18th ed. AOAC Int., Gaithersburg, MD, USA.

Atasoy, E., Altıngöz, Y. (2011). Dünya ve Türkiye'de Kestanenin Önemi ve Üretimi, İstanbul Üniversitesi Edebiyat Fakültesi Coğrafya Bölümü Coğrafya Dergisi 22, 1-13.

Bajwa, U., Mittal, S. (2013). Quality characteristics of no added sugar ready to drink milk supplemented with mango pulp. Journal of Food Science and Technology, 52(4), 21122120.

https://doi.org/10.1007/s13197-013-1184-7

Baysal, A. (2004). Beslenme. Hatiboğlu Yayınları, Ankara, Türkiye, p 268-275.

Bernárdez, M.M., De la Montaña Miguélez, J., Queijeiro, J.G. (2004). HPLC determination of sugars in varieties of chestnut fruits from Galicia (Spain). Journal of Food Composition and Analysis, 17(1), 63-67. https://doi.org/10.1016/S0889-1575(03)00093-0

Bounous, G., Botta, R., Beccaro, G. (2000). The chestnut: The Ultimate Energy Source Nutritional Value and Alimentary Benefits. NUCIS Newsletter, 9, 44-50.

Candemir, A. (2011). Determining of quality characteristics of sliced Chestnut dried in fluidized bed drier and Microwave drier. Izmir, Turkey: Univ.Ege. 
Dassler, E., Heitmann, G. (1991). Obst und gemüse, Berlin: Verlag Paul Parey, German. P. 56-58

De Vasconcelos, M.D.C.B.M., Bennett, R.N., Quideau, S., Jacquet, R., Rosa, E.A.S., Ferreira-Cardoso, J.V. (2010). Evaluating the potential of chestnut (Castanea sativa Mill.) fruit pericarp and integument as a source of tocopherols, pigments and polyphenols. Industrial Crops and Products, 31(2), 301-311.

https://doi.org/10.1016/j.indcrop.2009.11.008

De Vasconcelos, M.D.C.B.M., Bennett, R.N., Rosa, E.A.S., Cardoso, J.V.F. (2007). Primary and Secondary Metabolite Composition of Kernels from Three Cultivars of Portuguese Chestnut (Castanea sativa Mill.) at Different Stages of Industrial Transformation. Journal of Agricultural and Food Chemistry, 55(9), 3508-3516.

https://doi.org/10.1021/jf0629080

Demirci, M. (1984). Laktozun insan beslenmesindeki önemi, Atatürk Üniversitesi Ziraat Fakültesi Dergisi, 15, 3-4.

Diehl, J.F. (2002). Nuts shown to offer health benefits. International News on Fats, Oils and Related Materials, 13(2), 134-138.

Ertan, K., Bayana, D., Gokce, O., Alatossava, J.T., Yilmaz, Y., Gursoy, O. (2017). Total antioxidant capacity and phenolic content of pasteurized and UHT-treated cow milk samples marketed in Turkey. Akademik Gıda, 15, 103-108. https://doi.org/10.24323/akademik-gida.333630

Ertürk, Ü., Mert, C., Soylu, A. (2006). Chemical composition of fruits of some important chestnut cultivars. Brazilian Archives of Biology and Technology, 49(2), 183-188.

https://doi.org/10.1590/S1516-89132006000300001

FAO (2004). Calculation Of The Energy Content Of Foods Energy Conversion Factors.

http://www.fao.org/3/Y5022E/y5022e04.htm(accessed May, 2018).

Fox, P.F. (2003). Milk Proteins: General and Historical Aspects. In Fox, P.F \& McSweeney, P.L.H. (Eds.), Advanced Dairy Chemistry-1 Proteins (p. 1-48). Boston, MA: Springer.

https://doi.org/10.1007/978-1-4419-8602-3_1

Johnsen, D. (1992). B. Holland, I.D. Unwin und D.H. Buss: Vegetables, Herbs and Spices. The Fifth Supplement to McCance and Widdowson's The Composition of Foods (4th
Edition). 163 Seiten. Royal Society of Chemistry, Cambridge 1991. Preis: 24,50 £. Food Nahrung 36(4), 432-432.

https://doi.org/10.1002/food.19920360456

Inanc, A.L., Cınar, I. (2009). Alternatif doğal tatlandırıcı: Stevya. Gida, 34, 411-415.

Kırdar, S. (2001). Süt ve Ürünleri Analiz Metodları Uygulama Kilavuzu, Isparta, Süleyman Demirel Üniversitesi, Süt Yayınları, Isparta, Türkiye.

Kinghorn, A.D., Wu, C.D., Soejarto, D.D. (2001). Stevioside, In O'Brien Nabors, L. (Eds.), Alternative Sweeteners (p. 167-183). New York, NY: Marcel Dekker.

Miller, G.D., Jarvis, K.J., McBean, L.D. (2000). Handbook of Dairy Foods and Nutration, In Jensen, R.G. \& Kroger, M. (Eds.), Handbook of Dairy Foods and Nutrition. The Importance of Milk and Milk Products in the Diet (p. 4-24). New York, NY: CRC Press.

Naczk, M., Shahidi, F. (2004). Extraction and analysis of phenolics in food. Journal of Chromatography A, 1054(1-2), 95-111.

https://doi.org/10.1016/j.chroma.2004.08.059

Neri, L., Dimitri, G., Sacchetti, G. (2010). Chemical composition and antioxidant activity of cured chestnuts from three sweet chestnut (Castanea sativa Mill.) ecotypes from Italy. Journal of Food Composition and Analysis, 23(1), 2329.

https://doi.org/10.1016/j.jfca.2009.03.002

Nunes, A.P.M., Ferreira-Machado, S.C., Nunes, R.M., Dantas, F.J.S., De Mattos, J.C.P., Caldeira-de-Araújo, A. (2007). Analysis of genotoxic potentiality of stevioside by comet assay. Food and Chemical Toxicology, 45(4), 662666.

https://doi.org/10.1016/j.fct.2006.10.015

Paixão, J.A., Rodrigues, J.B., Esmerino, E.A., Cruz, A.G., Bolini, H.M.A. (2014). Influence of temperature and fat content on ideal sucrose concentration, sweetening power, and sweetness equivalence of different sweeteners in chocolate milk beverage. Journal of Dairy Science, 97(12), 7344-7353. https://doi.org/10.3168/jds.2014-7995

Selek, I. (2011). Research on some phenolic compounds of Walnut and chestnut. Ege University, Izmir, Turkey. 
Sonmez, C., Ertas, G., Okur, O.D., Güzel-Seydim, Z. (2010). UHT Sütlerin Bazı Kalite Kriterlerinin ve Antioksidan Aktivitelerinin Belirlenmesi. Akademik Glda, 8, 13-16.

Soylu, A. (2004). Kestane yetiştiriciliği ve özellikleri, Hasad yayıncılık Ltd.Şti, 2, p. 64

Unal, R.N., Besler, H.T. (2008). Süt ve Sütün Beslenmedeki Önemi, Sağlık Bakanlığı Yayın, Ankara, Türkiye.

Van Soest, P.J. (1994). Nutritional Ecology of the Ruminant.
USA. Cornell University Press, p. 476.

https://doi.org/10.7591/9781501732355

Vitali, D., Dragojević, I.V., Šebečić, B. (2009). Effects of incorporation of integral raw materials and dietary fibre on the selected nutritional and functional properties of biscuits. Food Chemistry, 114(4), 1462-1469.

https://doi.org/10.1016/j.foodchem.2008.11.032

Yurdakul, E. (2008). Evaluation of the quality criteria of freeze dried chestnut produced for enrichment of breakfast cereal products. Ege University, Izmir, Turkey. 